$\begin{array}{ll}\text { Volume } & : 04 \\ \text { Nomor } & : 02 \\ \text { Bulan } & : \text { Mei } \\ \text { Tahun } & : 2018 \\ \text { http } & : / / \text { jurnal.pps.ung.ac.id/index.php/AKSARA/index }\end{array}$

\title{
Penerapan Pendekatan Kontekstual (CTL) Pada Pembelajaran PAI Dalam Meningkatkan Hasil Belajar di Kelas V SDN 01 Duhiadaa.
}

\author{
Satmawati Masalubu \\ satmawatimasalubu@gmail.com
}

\begin{abstract}
Abstrak
Jenis penelitian ini merupakan Penelitian Tindakan Kelas (PTK) yang dilaksanakan dalam dua siklus. Subjek dalam penelitian ini adalah peserta didik kelas V SDN 01 Duhiadaa pada tahun pelajaran 2016/2017 yang berjumlah 30 orang yang terdiri dari 9 orang laki - laki dan 21 orang perempuan. Pengambilan data dalam penelitian ini dilakukan dengan menggunakan instrumen hasil belajar peserta didik, lembar pengamatan aktivitas guru dan pengamatan aktivitas peserta didik. Penelitian ini bertujuan untuk mengetahui peningkatan hasil belajar peserta didik pada pembelajaran (PAI) melalui penerapan pendekatan kontekstual (CTL). Berdasarkan hasil analisis data menunjukan bahwa terjadi peningkatan terhadap hasil belajar peserta didik pada pembelajaran PAI melalui penerapan pendekatan kontekstual (CTL). Hasil belajar pada siklus I jumlah peserta didik yang memperoleh nilai tuntas atau mendapat nilai 75 keatas ada 18 orang $(60 \%)$ dan pada siklus II meningkat menjadi 26 orang $(86,67 \%)$. Dengan demikian, pembelajaran melalui penerapan pendekatan kontekstual (CTL) sangat efektif digunakan pada pembelajaran Pendidikan Agama Islam (PAI) dalam meningkatkan hasil belajar peserta didik kelas V SDN 01 Duhiadaa tahun pelajaran 2016/2017
\end{abstract}

Kata kunci: Pembelajaran PAI, Tes Hasil Belajar, Pendekatan Kontekstual

\section{Pendahuluan}

Peningkatan hasil belajar peserta didik perlu dilakukan secara terus menerus pada semua mata pelajaran termasuk Pendidikan Agama Islam (PAI). Hal tersebut dikarenakan pendidikan agama memiliki peranan dan posisi yang sangat strategis dalam kehidupan manusia sebagai tata nilai, pedoman, pembimbing, dan pendorong atau penggerak untuk mencapai kwalitas hidup yang lebih baik.

Pemerintah menempatkan Pendidikan Agama Islam (PAI) sebagai khasanah bangsa yang harus dilestarikan dan ditumbuhkembangkan dikalangan peserta didik sejak Taman Kanak-kanak sampai Perguruan Tinggi. Pada setiap jenjang dan jenis pendidikan, PAI menjadi mata pelajaran wajib yang harus ditempuh semua peserta didik (terutama yang bergama Islam) tanpa terkecuali. Tuntutan ke arah itu cukup beralasan untuk menggiring proses pembelajaran PAI agar mampu menciptakan iklim kondusif bagi perkembangan kepribadian peserta didik, sehingga menjadi manusia yang berguna bagi agama, bangsa dan negara.

Berhasilnya tujuan pembelajaran ditentukan oleh banyak faktor diantaranya adalah faktor guru dalam melaksanakan proses belajar mengajar, karena guru secara langsung dapat mempengaruhi, membina dan meningkatkan kecerdasan serta keterampilan peserta didik. Untuk mencapai tujuan pendidikan secara maksimal, peran guru sangat penting dan diharapkan guru mampu menyampaikan semua mata 


$\begin{array}{ll}\text { Volume } & : 04 \\ \text { Nomor } & : 02 \\ \text { Bulan } & : \text { Mei } \\ \text { Tahun } & : 2018 \\ \text { http } & : / / \text { jurnal.pps.ung.ac.id/index.php/AKSARA/index }\end{array}$

pelajaran yang tercantum dalam proses pembelajaran secara tepat dan sesuai dengan konsep-konsep mata pelajaran yang akan disampaikan.

Namun sejauh ini fakta menunjukkan penyajian metode-metode, model dan pendekatan pembelajaran yang diterapkan dalam pembelajaran PAI selama ini masih menggunakan yang konvensional. Kebayakan para pendidik menggunakan metode ceramah, karena metode ini dianggap paling sederhana sehingga yang terjadi dilapangan peserta didik cenderung tidak memahami materi yang disampaikan oleh guru. Peserta didik lebih banyak bermain, baik pada saat proses belajar mengajar di kelas berlangsung maupun di luar kelas dan sekolah. Hal ini mengakibatkan hasil belajar peserta didik khususnya peserta didik kelas V SDN 01Duhiadaa pada mata pelajaran PAI tergolong masih rendah.

Salah satu upaya yang dipilih oleh guru untuk meningkatkan hasil belajar yang cenderung rendah adalah dengan memilih pendekatan pembelajaran yang tepat yaitu salah satunya pendekatan kontekstual atau contextual teacher learning (CTL). Pendekatan konteksual ini merupakan salah satu pendekatan pembelajaran yang membantu guru membawa peserta didik kedalam dunia nyata. Karena pendekatan kontekstual ini merupakan pendekatan yang mengaitkan materi dengan situasi dunia nyata dan mendorong peserta didik membuat hubungan anatar penegtahuan yang dimilikinya dengan penerapannya dalam kehidupan mereka.

Oleh karena itu melalui pendekatan kontekstual ini diharapkan peserta didik akan berhasil dalam mengikuti proses pembelajaran pendidikan agama Islam (PAI). Penggunaan pendekatan kontekstual (CTL) dimaksudkan untuk mempermudah peserta didik dalam mengikuti pembelajaran sehingga peserta didik terlibat secara aktif dan tidak merasa cepat bosan dalam mengikuti proses pembelajaran.

\section{Kajian Teori \\ Tes Hasil Belajar}

Tes sebagai alat penilaian adalah pertanyaan-pertanyaan yang diberikan kepada siswa untuk mendapatkan jawaban dari siswa dalam bentuk lisan, atau bentuk tulisan. Tes pada umumnya digunakan untuk menilai dan mengukur hasil belajar siswa, terutama hasil belajar kognitif berkenaan dengan penguasaan bahan pelajaran yang sesuai.

Tes dapat dipilah-pilah ke dalam berbagai kelompok. Bila dilihat konstruksinya maka tes dapat diklasifikasikan sebagai berikut:

(1) menurut bentuknya: tes bentuk uraian dan tes bentuk objektif,

(2) menurut tipenya: butir tes uraian dapat diklasifikasikan ke dalam dua tipe, yaitu tes uraian terbatas, dan tes uraian bebas. Butir tes objektif menurut tipenya dapat dibagi menjadi tiga, yaitu tes benar-salah, butir tes menjodokan, dan butir tes pilihan ganda. Dalam penelitian ini tes yang digunakan adalah tes uraian.

Proses adalah kegiatan yang dilakukan oleh siswa dalam mencapai tujuan pengajaran, sedangkan hasil belajar adalah kemampuan-kemampuan yang dimiliki siswa setelah ia menerima pengalaman belajar. Dalam sistem Pendidikan Nasional rumusan tujuan pendidikan, baik tujuan kurikuler maupun tujuan instruksional, menggunakan klasifikasi hasil belajar dari Benyamin Bloom yang secara garis besar membaginya menjadi tiga ranah yakni ranah kognitif, ranah afektif, dan ranah psikomotoris. 


$\begin{array}{ll}\text { Volume } & : 04 \\ \text { Nomor } & : 02 \\ \text { Bulan } & : \text { Mei } \\ \text { Tahun } & : 2018 \\ \text { http } & : \text { //ejurnal.pps.ung.ac.id/index.php/AKSARA/index }\end{array}$

Ranah kognitif berkenaan dengan hasil belajar intelektual yang terdiri dari tiga aspek, yakni pemahaman konsep, penalaran dan komunikasi, dan pemecahan masalah. Ranah afektif berkenaan dengan sikap yang terdiri dari lima aspek yakni penerimaan, jawaban atau reaksi, penilaian, organisasi, dan internalisasi. Ranah psikomotoris berkenaan dengan hasil belajar keterampilan dan kemampuan bertindak.

Ketiga ranah tersebut menjadi objek penilaian hasil belajar. Di antara ketiga ranah tersebut, ranah kognitif dan afektif yang paling banyak dinilai oleh guru dan sekolah karena berkaitan dengan kemampuan dan sikap para siswa dalam menguasai isi materi pelajaran. Dalam penelitian ini kemampuan hasil belajar siswa yang dinilai hanya berhubungan dengan ranah kognitif dan afektif saja.

Sedangkan 5 (lima) ranah afektif yang diuraikan di atas diukur dengan aktivitas-aktivitas, yaitu mendengar/memperhatikan penjelasan guru, membaca buku/LKS, bekerja dalam kelompok/mengerjakan LKS/ menggunakan/ memperagakan alat peraga/ menulis hal yang relevan dalam KBM, bertanya pada guru/siswa, dan perilaku yang tidak relevan dalam KBM.

\section{Pendekatan Kontekstual}

Secara harfiah, kontekstual berasal dari kata contextyang berarti "hubungan, konteks, suasana,dan keadaan konteks". Sehingga, pembelajaran kontekstual diartikan sebagai pembelajaran yang berhubungan dengan konteks tertentu. Menurut Suprijono (2009: 79), pendekatan pembelajaran kontekstual atau Contexstual Teaching and Learning (CTL) merupakan konsep yang membantu guru mengaitkan antara materi yang diajarkannya dengan situasi dunia nyata,dan mendorong siswa membuat hubungan antara pengetahuan yang dimilikinya dengan penerapannya dalam kehidupan mereka sebagai anggota keluarga dan masyarakat.

Pendekatan pembelajaran kontekstual merupakan prosedur pendidikan yang bertujuan membantu siswa memahami makna bahan pelajaran yang mereka pelajari,dengan cara menghubungkannya dengan konteks kehidupan mereka sendiri dalam lingkungan sosial dan budaya masyarakat. Sehingga, proses belajar tidak hanya berpengaruh pada hasil belajar yang menjadi tujuan pembelajaran, namun memberikan kebermaknaan pengetahuan dan pengalaman yang bermanfaat dalam konteks dunia nyata siswa

Jhonson (2006: 15) mengungkapkan bahwa pendekatan kontekstual adalah pembelajaran yang bertujuan menolong siswa melihat makna di dalam materi akademik dengan konteks kehidupan keseharian mereka, yaitu dengan konteks keadaan pribadi, sosial, dan budaya mereka. Hal ini berarti,bahwa pembelajaran kontekstual memungkinkan siswa menghubungkan isi materi dengan konteks kehidupan sehari - hari untuk menemukan makna.

Sanjaya (2006: 109) mengemukakan bahwa pendekatan pembelajaran kontekstual adalah suatu pendekatan pembelajaran yang menekankan kepada proses keterlibatan siswa secara penuh, untuk dapat memahami materi yang dipelajari, dan menghubungkannya dengan situasi kehidupan nyata,sehingga mendorong siswa untuk dapat menerapkannya dalam kehidupan mereka. Penjelasan lebih lanjut dikemukakan oleh Muchith (2008: 86), bahwa pendekatan kontekstual merupakan pembelajaran yang bermakna dan menganggap tujuan 


$\begin{array}{ll}\text { Volume } & : 04 \\ \text { Nomor } & : 02 \\ \text { Bulan } & : \text { Mei } \\ \text { Tahun } & : 2018 \\ \text { http } & : / / \text { jurnal.pps.ung.ac.id/index.php/AKSARA/index }\end{array}$

pembelajaran adalah situasi yang ada dalam konteks tersebut, konteks itu membantu siswa dalam belajar bermakna dan juga untuk menyatakan hal - hal yang abstrak

Berdasarkan beberapa pendapat yang telah dikemukakan para ahli, peneliti menyimpulkan bahwa pendekatan kontekstual merupakan pendekatan dengan konsep belajar mengajar yang mengaitkan antara materi yang diajarkan oleh guru dengan situasi dunia nyata siswa, dan mendorong siswa untuk membuat hubungan antara pengetahuan yang dimilikinya dengan penerapannya dalam kehidupan nyata

\section{Metode Penelitian}

Penelitian ini dilakukan di kelas V SDN 01 Duhiadaa Kabupaten Pohuwato. Penulis mengambil lokasi atau tempat ini dengan pertimbangan bekerja pada sekolah tersebut, sehingga memudahkan dalam mencari data, peluang waktu yang luas dan subyek penelitian yang sangat sesuai dengan profesi penulis.

Subyek dalam penelitian ini adalah peserta didik SDN 01 Duhiadaa yang duduk di kelas V pada tahun pelajaran 2016/2017 dengan jumlah peserta didik kelas $\mathrm{V}$ ada 30 orang dan terdiri dari 9 orang laki-laki dan 21 orang perempuan

Langkah - langkah yang dilakukan untuk setiap siklus pembelajaran dalam prosedur penelitian ini adalah sebagai berikut :

a. Tahapan Persiapan

Sebelum melaksanakan tindakan, peneliti perlu mengadakan persiapan, sehingga semua komponen yang direncanakan dapat dikelola dengan baik. Berikut ini adalah langkah-langkah yang ditempuh sebelum melaksanakan penelitian.

1. Melapor dan meminta izin Kepala Sekolah;

2. Mengidentifikasi masalah;

3. Menyusun rencana kegiatan penelitian secara menyeluruh;

4. Menetapkan waktu pelaksanaan penelitian;

5. Membuat alat evaluasi sebagai dasar dalam mempertimbangkan pelaksanaan tindakan.

b. Tahap Pelaksanaan Tindakan

\section{Siklus I}

1. Mengadakan apersepsi;

2. Melaksanakan penelitian tindakan kelas sesuai dengan metode mata pelajaran yang direncanakan;

2. Memantau proses belajar mengajar dengan segala unsur;

3. Mengadakan evaluasi dengan tes tertulis;

4. Menganalisis hasil pemantauan dengan tes;

5. Mengadakan refleksi terhadap hasil pemantauan dan hasil tes.

Jika siklus I dipandang belum memuaskan hasilnya maka pelaksanaan tindakan kelas dilanjutkan dengan siklus berikutnya.

Siklus II

1. Merumuskan tindakan baru;

2. Melaksanakan tindakan baru;

3. Mengevaluasi hasil pemantauan;

4. Mengadakan refleksi. 


$\begin{array}{ll}\text { Volume } & : 04 \\ \text { Nomor } & : 02 \\ \text { Bulan } & : \text { Mei } \\ \text { Tahun } & : 2018 \\ \text { http } & : / / \text { jurnal.pps.ung.ac.id/index.php/AKSARA/index }\end{array}$

Jika siklus II dipandang sudah memuaskan hasilnya maka pelaksanaan tindakan kelas tidak perlu dilanjutkan ke siklus berikutnya.

c. Tahap pemantauan evaluasi

Pada tahap ini peneliti melakukan dua jenis kegiatan sekaligus yakni pemantauan yang dibantu oleh kolaborator (teman sejawat) dan penilaian hasil belajar peserta didik dalam pembelajaran. Kegiatan ini bertujuan untuk melihat apakah hasil belajar tersebut tetap seperti perolehan hasil pada siklus-siklus yang telah dilaksanakan. Untuk mempermudah penelitian ini, maka peneliti menggunakan alat atau instrumen berupa lembar observasi, dan tes hasil belajar.

d. Tahap analisis dan refleksi.

Pada tahap refleksi ini, bila hasil yang diharapkan belum tercapai pada siklus I, maka tindakan masih perlu dilanjutkan pada siklus II, sebab tahap ini bertujuan untuk mengetahui sejauh mana kemajuan dari siklus yang dilakukan, hal apa saja yang belum sempurna dan yang harus diperbaiki pada siklus selanjutnya.

Sumber data dalam penelitian ini adalah peserta didik dan guru sebagai anggota peneliti. Dengan jenis data tentang hasil belajar yang diperoleh peserta didik dan data tentang proses pembelajaran dengan menggunakan pendekatan kontekstual Yang menjadi indikator keberhasilan adalah jika hasil belajar ada peningkatan minimal $80 \%$ dari seluruh peserta didik yang mendapat tindakan mencapai skor diatas 75

\section{Hasil Penelitian}

Data hasil belajar peserta didik pada pelaksanaan evaluasi siklus I secara sederhana hasilnya dapat dilihat pada tabel berikut.

Tabel 1

Data Hasil Belajar Siklus I

\begin{tabular}{|c|c|c|}
\hline Rentang Nilai & Jumlah & Persentase \\
\hline $85-100$ & 9 & 30 \\
\hline $75-84$ & 9 & 30 \\
\hline $45-74$ & 6 & 20 \\
\hline $0-44$ & 6 & 20 \\
\hline Jumlah & $\mathbf{3 0}$ & $\mathbf{1 0 0}$ \\
\hline \multicolumn{2}{|c|}{ Persentase nilai $\geq 75=60 \%$} \\
\hline \multicolumn{2}{|c|}{ Persentase nilai $\leq 74=40 \%$} \\
\hline
\end{tabular}

Dilihat dari tabel diatas pada pelaksanaan evaluasi siklus I ini diikuti oleh 30 orang. Berdasarkan rekapitulasi perolehan nilai peerta didik yang memperoleh nilai tuntas atau mendapat nilai 75 keatas sebanyak 18 orang (60\%), sedangkan peserta didik yang memperoleh nilai 75 kebawah sebanyak 12 orang (40\%). Berdasarkan hasil evaluasi maka hasil belajar peserta didk pada pembelajaran PAI belum mencapai indikator keberhasilan. Dari hasil yang diperoleh pada siklus I terlihat bahwa hasil belajar pada peserta didik kelas V SDN 01 Duhiadaa sudah mengalami peningkatan meskipun belum optimal. Oleh karena itu peneliti dan kolaborator masih ingin melanjutkan pelaksanaan siklus kedua dengan alasan agar hasil belajar dapat meningkat sesuai dengan indikator keberhasilan yang telah ditetapkan. 


$\begin{array}{ll}\text { Volume } & : 04 \\ \text { Nomor } & : 02 \\ \text { Bulan } & : \text { Mei } \\ \text { Tahun } & : 2018 \\ \text { http } & : \text { //ejurnal.pps.ung.ac.id/index.php/AKSARA/index }\end{array}$

Data hasil belajar pada pelaksanaan evaluasi siklus II secara sederhana hasilnya dapat dilihat pada tabel berikut.

Tabel 2

Data Hasil Belajar Siklus II

\begin{tabular}{|c|c|c|}
\hline Rentang Nilai & Jumlah & Persentase \\
\hline $85-100$ & 11 & 36,67 \\
\hline $75-84$ & 15 & 50,00 \\
\hline $45-74$ & 4 & 13,33 \\
\hline $0-44$ & - & - \\
\hline Jumlah & $\mathbf{3 0}$ & $\mathbf{1 0 0}$ \\
\hline \multicolumn{2}{|c|}{ Persentase nilai $\geq 75=86,67 \%$} \\
\hline \multicolumn{2}{|c|}{ Persentase nilai $\leq 74=13,33 \%$} \\
\hline
\end{tabular}

Dilihat dari tabel diatas pada pelaksanaan evaluasi siklus II ini diikuti oleh 30 orang. Berdasarkan rekapitulasi perolehan nilai peserta didik yang memperoleh nilai tuntas atau mendapat nilai 75 keatas sebanyak 26 orang $(86,67 \%)$, sedangkan siswa yang memperoleh nilai 75 kebawah sebanyak 4 orang (13,33\%). Berdasarkan hasil evaluasi maka hasil belajar siswa telah mencapai indikator keberhasilan

Dari hasil yang diperoleh pada siklus II terlihat bahwa telah terjadi peningkatan yang diharapkan. Dari hasil refleksi dan deskripsi data yang telah diuraikan di atas, jelas bahwa peningkatan yang diharapkan telah terjadi sesuai dengan indikator kinerja bahkan melebihi indikator yang telah ditetapkan. Penelitian ini tidak perlu dilanjutkan lagi pada siklus berikutnya.

\section{Pembahasan}

Tujuan pelaksanaan penelitian tindakan kelas adalah untuk mencari suatu solusi yang tepat terhadap kendala yang dihadapi pada pembelajaran PAI. Penyajian materi yang cenderung monoton menyebabkan hasil belajar mengalami penurunan. Oleh sebab itu, peneliti mencoba menerapkan suatu pendekatan pembelajaran yaitu pendekatan kontekstual (contextual teaching and learning) atau yang dikenal dengan pendekatan CTL, dengan tujuan untuk meningkatkan hasil belajar pembelajaran PAI. Adapun perangkat yang digunakan untuk menunjang hasil penelitian adalah lembar pengamatan aktivitas guru, pengamatan aktivitas peserta didik, dan tes hasil belajar.

Pada siklus I, pengelolaan pembelajaran telah dilaksanakan oleh guru, namun masih terdapat beberapa aspek yang belum tuntas. Hal ini disebabkan oleh kurangnya persiapan peneliti dalam pembelajaran, sehingga pengelolaan pembelajaran menjadi kurang optimal. Kekurangan ini kemudian diperbaiki pada siklus II. Hasil yang diperoleh pun sangat memuaskan. Peneliti mampu mengelola pembelajaran dengan baik karena sebelum pembelajaran dimulai, peneliti telah melakukan persiapan yang optimal.

Sedangkan hasil belajar yang diperoleh pada Siklus I dan Siklus II, yang menunjukkan peningkatan hasil belajar pada pembelajaran PAI. Hal ini disebabkan karena pendekatan kontekstual mengaitkan materi pembelajaran dengan kehidupan nyata sehingga peserta didik dapat menjadi lebih aktif dalam mengikuti proses pembelajaran 


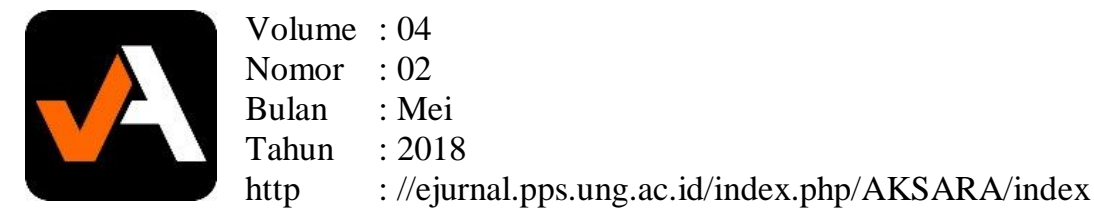

Berdasarkan deskripsi hasil penelitian dan pembahasan yang telah dipaparkan di atas, maka jelaslah bahwa penggunaan pendekatan kontekstual berhasil meningkatkan hasil belajar pembelajaran PAI pada siswa kelas V SDN 01 Duhiadaa Kabupaten Pohuwato karena sudah sesuai dengan indikator yang ditetapkan.

\section{Kesimpulan}

Berdasarkan hasil penelitian dan pembahasan, maka dapat disimpulkan bahwa pendekatan kontekstual dapat meningkatkan hasil belajar pembelajaran PAI di kelas V SDN 01 Duhiadaa. Hal ini dapat dilihat pada hasil belajar yang dicapai peserta didik mengalami peningkatan dari 30 orang yang mendapat tindakan melalui pendekatan kontekstual pada siklus I (nilai 75 keatas) ada 18 orang (60\%) sedangkan pada siklus II meningkat menjadi 26 orang (86,67\%). Dengan demikian indikator keberhasilan telah tercapai

\section{DAFTAR PUSTAKA}

Abdulmajid dan Dian Andatani. 2004. Pendidikan Agama Islam Berbasis Kompetensi. Bandung : PT. Remaja Rosdakarya

Aburrahman Mulyono. 1999. Pendidikan Bagi Siswa Berkesulitan Belajar. Jakarta: Rineka Cipta.

Djamarah, Rosmala. 1994. Penilaian terhadap Hasil Belajar Siswa. Jakarta: Pustaka Jaya

Jonshon, Elanie B. 2011. CTL Contextual Teaching And Learning : Menjadikan Kegiatan Belajar Mengajar Mengasyikkan dan Bermakna. Bandung : Kaifa.

Komalasari, Kokom. 2010. Pembelajaran Kontekstual : Konsep dan Aplikasi. Bandung : PT. Rafika Aaditama

Muhaimin. 2002. Paradigma Pendidikan Islam. Bandung: PT. Remaja Rosdakarya

Nurhadi, dkk. 2003. Pembelajaran Konstekstual (Cooperatif Learning di Ruangruang Kelas). Jakarta: Gramedia Widiasarana

Pandoyo. 1992. Strategi Belajar Mengajar. Semarang:IKIP Semarang Press.

Purwanto. 2011. Evaluasi Hasil Belajar. Yogyakarta : Pustaka Pelajar

Sudjana, Nana. 2013. Penilaian Hasil Proses Belajar Mengajar. Bandung : PT Remaja Rosdakarya 


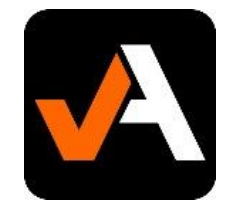

Volume : 04

Nomor : 02

Bulan : Mei

Tahun : 2018

http : //ejurnal.pps.ung.ac.id/index.php/AKSARA/index

Uno, Hamzah B. 2009. Model Pembelajaran (Menciptakan Proses Belajar Mengajar yang Kreatif dan Efektif). 2009. PT. Bumi Aksara

Wina, Sanjaya. 2012. Penelitian Tindakan Kelas. Jakarta : Kencana Prenada Media Group 